\title{
Enterprise Risk Management In Private Firms: Does Ownership Structure Matter?
}

Elisabetta Mafrolla, University of Foggia, Italy

Felice Matozza, University of Rome Three, Italy

Eugenio D'Amico, University of Rome Three, Italy

\begin{abstract}
Private firms adopt Enterprise Risk Management (ERM) practices voluntarily. Using results of a survey that involved 78 respondents, we investigate the adoption of ERM practices in Italian private corporations and question whether ERM adoption is affected by the ownership structure of the firm. We find that agency conflicts between controlling and minority shareholders, which arise when ownership dispersion decreases, affect ERM adoption, and that when proprietorship is more dispersed, the firm places more focus on ERM projects. Additionally, we document the different roles of different types of owners. More specifically, in line with the patronage agency theory, the government-controlled enterprises undergo more intense ERM, whereas, in line with behavioral agency theory, individual and family-controlled firms pay less attention to ERM adoption.
\end{abstract}

Keywords: Enterprise Risk Management; Agency Conflict; Ownership Concentration; Type of Ownership; Private Firms

\section{INTRODUCTION}

$\mathrm{n}$ spite of the growing attention paid to Enterprise Risk Management (ERM) in listed firms (McShane et al., 2011; Hoyt \& Liebenberg, 2011; Pagach \& Warr, 2011), there is relatively little research examining its implementation in smaller and unlisted corporations. Two main reasons account for such a lack in the published research. Firstly, no code of self-regulation pushes private firms into ERM implementation, meaning that they adopt ERM practices (if any) voluntarily; public firms, however, are compelled to adopt the generally accepted standards of ERM. Secondly, accounting and non-accounting information about private firms are often protected by confidentiality; therefore, studying managerial behaviors in private firms relies on primary data collection, which is expensive in terms of time and money, and suffers the feasibility of sample and collection bias. Nevertheless, ERM might be profitable to all organizations, including private corporations (Gates et al., 2012; COSO, 2004). Considering that ERM is likely to reduce firms' risk exposure, the issue of ERM implementation in private firms is important as, when compared to their public counterparts, they are more likely to encounter financial difficulties and face default. Besides, due to the undiscussed relevance of private businesses in today's economy, the investigation of ERM in private firms is a desirable and fascinating field of study.

In this paper, our contribution is to fill the gap in the literature by empirically investigating the issue of ERM within private firms. By administering a survey to a sample from Italy, where corporate governance is characterized by a high level of ownership concentration and a lack of adequate protection of minority investors, we measure the degree of adoption of ERM practices and question whether ownership features have an impact on ERM practices. We use econometric regression analysis in order to examine whether ERM is affected by agency conflicts arising from ownership dispersion and type of ownership.

We contribute to the existing literature in several ways. We demonstrate that even though the management is not pushed into adopting published frameworks, the degree of implementation of ERM is affected primary by the ownership features of a firm, while performance has relatively limited explanatory power. From a theoretical perspective, we consider in our work the relevance of agency theory, the need to mitigate conflicts between the controlling and the minority shareholders (so-called Type II Agency Conflicts) and their influence over ERM adoption. 
The rest of the paper follows the outline given below. Section Two both reviews the existing literature dealing with ERM adoption in listed and non-listed corporations and situates agency theory within the framework of private firms. The third section outlines the development of the hypothesis tested in this research; it defines the variables and the econometric model adopted in the empirical tests. In the fourth section, the sample is described. The fifth section shows results and discusses findings and, finally, the sixth section briefly concludes the paper.

\section{LITERATURE REVIEW}

\subsection{ERM in Public and Private Firms}

ERM, and fundamental changes regarding the management of risks, have attracted a great deal of interest over the last decade. Scholars and practitioners have experienced a radical shift from a silo-based perspective (using a rigid, compartmentalized and fragmented way of managing risks) to a more coordinated management of all risks, so-called ERM, which also permits a more comprehensive understanding of the connected impacts amongst the full spectrum of risks (Gordon et al., 2009; Kleffner et al., 2003; Beasley et al., 2008; Liebenberg \& Hoyt, 2003). This new approach allows companies to go beyond the traditional financial aspect; in fact, ERM is geared towards the achievement of strategic goals (Beasley et al., 2015; Sarens \& De Beelde, 2006; Maurer, 2009). Corporations, regulators, as well as investors, recently enhanced the focus on ERM practices (Liebenberg \& Hoyt, 2003; Beasley et al., 2008; Demidenko \& McNutt, 2010), especially in the aftermath of the global crisis (Baxter et al., 2013), as it was considered to be a source of competitive advantage during and after the economic downturn (Nair et al., 2014; Ellul \& Yerramilli, 2013). In the light of prominent financial scandals, Standard and Poor's began in 2007 to measure the degree to which an insurer implemented an ERM program. In the following year, Standard and Poor's introduced ERM analysis into the credit-rating process of non-financial companies. Nowadays, ERM is an essential element of corporate governance (Spira \& Page, 2003; Bhimani, 2009), but prior studies have mainly investigated ERM in listed or financial corporations.

Whereas a stream of research has examined the relevance of ERM for firm performance and firm value (Andersen, 2008; Liebenberg \& Hoyt, 2003; Hoyt \& Liebenberg, 2011; McShane et al., 2011), a series of empirical analyses have addressed the issue of ERM in listed and non-listed firms comparatively, but the results are contradictory. Some of them (Institute of Chartered Accountants in England and Wales, 2005; Paape \& Speklé, 2012) proved that listed firms have more developed ERM systems than those of non-listed organizations, inasmuch as they are hindered by the absence of a common framework for their adoption. A variety of studies, some of which drew upon institutional theory (DiMaggio \& Powell, 1983), reported that coercive pressures, which change from country to country, affected companies' ERM systems strongly (Demidenko \& McNutt, 2010; Sarens \& Christopher, 2010; Arena \& Azzone, 2007), as did the pivotal or trivial roles played by internal auditors in promoting and practicing effective risk management (Arena et al., 2006; Sarens \& De Beelde, 2006). On the contrary, Kleffner et al. (2003), Beasley et al. (2015) and Baxter et al. (2013) surprisingly found no significant difference in the propensities of private and public firms to adopt ERM practices.

Hence, evidence about the adoption of ERM practices by private corporations is fairly mixed since ERM is timeand context-specific; it depends on the capabilities and willingness of a company's staff and it is now evolving rapidly, especially within private corporations (Beasley et al., 2015).

Although Paape and Speklé (2012) assert that firms might easily avoid corporate governance regulations, highlighting the fact that only mandatory enforcement is effective in shaping their behavior, firms should not only embrace minimal elements of ERM merely to comply with regulatory pressure, following institutional theory (Blaskovich et al., 2012), they should also value it and consider the benefits that might be reaped from its proper adoption (Spira \& Page, 2003; Gates et al., 2012; Hoyt \& Liebenberg, 2011). For instance, the German Control and Transparency Act (known in the literature as the KonTraG regime) has mandated ERM engagement for all publicly listed firms in Germany since 1998, with the result that earnings' quality and capital resource allocation have been improved (Brown et al., 2014). ERM should not be perceived as a bureaucratic process; its activities provide precious and reliable information utilizable by decision-makers (Fraser \& Henry, 2007; De Zwaan et al., 2011; Arena \& Azzone, 2009). 
ERM in non-listed companies has been attributed a low priority in the relevant literature. These firms are often unable to hire employees with the necessary expertise, technical knowledge and availability for training: factors that foster ERM capabilities (Gao et al., 2013). Moreover, private firms seldom have formal risk-reporting procedures or internal ERM regulations (Henschel, 2010; Gao et al., 2013). Lastly, there is no tendency for smaller firms to adopt advanced ERM practices, such as the use of quantitative techniques for risk identification and measurement, the enrollment of a professionally qualified risk manager or chief risk officer or the settlement of a dedicated risk management department (Tagliavini, 1995; Petroni, 1999; Mafrolla \& Matozza, 2014). The application of ERM in small and medium-sized enterprises may be effective, despite the limitations they often experience.

\subsection{Overview of Theoretical Perspectives}

In US-based corporations, consistent with the agency theory perspective, shareholders ask explicitly for more stringent monitoring of the management's actions (so-called Type I Agency Conflict) by increasing the level of engagement in ERM activities, which enhances shareholders' protection (Beasley et al., 2015). In a different institutional context where ownership is concentrated in the hands of the main block-shareholder (such as the Italian context), less effort is put into controlling the management's actions (Melis, 2000; La Porta et al., 1999; Shleifer \& Vishny, 1997), as the manager is an affiliate of the owner (Shleifer \& Vishny, 1997). In such a context, a so-called Type II Agency Conflict arises between the large controlling shareholder and a fringe of small minority shareholders.

Focusing on private firms, rather than the possibility of investigating public companies, offers the best testing ground for the relationship between ERM and the ownership structures of firms, as long as private firms have less dispersed ownership (Hope, 2013) and offer more heterogeneous ownership features (Hope et al., 2012). Finally, in private firms the separation of ownership and management (the Type I Agency Conflict) is rare, whilst the Type II Agency Conflicts are likely to arise. In such a context, ERM practices are adopted voluntarily by private firms.

An interesting stream of literature documents the fact that the type of ownership matters in corporate governance choices, and that various types of owner experience the agency conflicts differently and act differently, in order to mitigate conflicts and improve their positions in their respective corporations.

With this paper we wish to reply to recent calls for further research dealing with types of ownership and corporate governance (Kumar and Zattoni, 2014), and investigate the under-studied field of ERM as a governance tool for private firms.

\section{HYPOTHESIS DEVELOPMENT}

Due to the agency conflicts that arise between the controlling shareholders and the minority shareholders in private firms, especially in the Italian scenario (Melis, 2000), we forecast that ownership concentration constitutes a dominant driving force in our study. Large shareholders have an interest in increasing their control over the organizations in which they have invested by monitoring management more closely, sitting on the board or hiring affiliate managers. On the contrary, small shareholders have an incentive to engage with a robust internal control mechanism and establish other sound corporate governance controls for monitoring the management's actions. Indeed, managers may collude with large shareholders by exploiting a lack of corporate governance (and ERM) for personal interests. As a result, the minority shareholders may be worried about expropriation, and for all of these reasons they might try to pressurize the management into improving ERM processes, which could help to maximize shareholders' value protection. Thus, we hypothesize that ERM adoption could be affected by the extent of ownership dispersion, and that a large number of owners could implement ERM practices more effectively in private corporations where Type II Agency Conflicts dominate. Accordingly, our first proposition is as follows:

Hypothesis 1: There is a positive influence exerted by ownership dispersion on the adoption of ERM practices.

Large shareholders behave differently, and every category of owner has different incentives in expropriating rights and extracting rents from the firm at the expense of minority shareholders, because agency conflicts are shaped differently by both ownership concentration and ownership type, constituting the so-called ownership structure of 
the firm (Round, 1976). We tested the idea that various types of shareholders affect ERM adoption differently. Hence, we tested the following hypothesis:

Hypothesis 2: Different impacts attend different types of main block-ownership on the adoption of ERM practices.

We focused on three different types of block-shareholders: institutional investors, governmental owners and general industrial (individual or company) owners.

Firstly, we analyzed whether firms controlled by institutional owners develop better ERM practices. The degree of institutional ownership was found to be a significant determinant in ERM application (Pagach \& Warr, 2011), because an institutional owner who is also a minority shareholder is bound to demand high-quality information (Kane \& Velury, 2004). There is much discussion on whether institutional owners, when they are the main blockholders of their firms, can be active managers and focus on long-term oriented and low-risk operations (Chaganti \& Damanpour, 1991). In the context of large share-ownership concentration, we suspect that the institutional investor is likely to be a professional main blockholder, keen to improve the quality of the firm's management. They will probably implement a stronger ERM, mitigating the Type II Agency Conflict, also taking into consideration the fact that institutional investors often have competencies, abilities and finances inside to help subsidiaries to engage in formal ERM actions. Nevertheless, the issue of the role of institutional block-ownership in private firms remains largely unexplored, as most existing studies focus on publically traded firms. Hence, we expand Hypothesis 2 into the following sub-hypotheses:

Hypothesis 2.a: There is a positive impact of institutional main block-ownership on the adoption of ERM practices.

As a second category of ownership, we focused on general industrial (company or individual) owners, which, in the context of private firms, likely include a majority of family owners. When a firm's decisions are made by an ownermanager or by a family owner, there is a strong likelihood that engagement in ERM will be lower (Brustbauer, 2016; Paape \& Speklé, 2012), as they tend to be less apt to engineer a formal control system (Lovata \& Costignan, 2002). Following the behavioral agency theory (Wiseman \& Gomez-Mejia, 1998), a high degree of control and influence exerted by the family on the firm can be detrimental to its governance and, in a context of high ownership concentration, it can exacerbate the Type II Agency Conflict (Berrone et al., 2012). These statements led us to conjecture that firms controlled by general industrial companies are likely to result in weaker ERM practices. Thus, we tested the following sub-hypothesis:

Hypothesis 2.b: There is a negative impact of general industrial main block-ownership on the adoption of ERM practices.

As a third and final category, we considered government-owned firms (Niemi, 2005; Hope, 2013) as, following the patronage agency theory (Shleifer \& Vishny, 1994), the government is likely to be a stakeholder-focused investor. Consequently, we expect that government block-ownership mitigates the Type II Agency Conflict, warrants higher protection for shareholders and is a more effective monitor of management for reputational purposes (Ali \& Lesage, 2013). Consequently, we tested:

Hypothesis 2.c: There is a positive impact of governmental main block-ownership on the adoption of ERM practices.

\subsection{Dependent Variable: The Measurement of the Adoption of ERM Practices}

In line with Beasley et al. (2015), we developed an index in order to measure the various levels of implementation of ERM across firms. Our index-based approach for ERM deployment differs from the binary-indicator-based approach adopted by other researchers as a proxy for the adoption of ERM practices, who either refer to a firm's decision to hire a chief risk officer, or refer to whether a firm is engaged in ERM (Beasley et al., 2008; Liebenberg \& Hoyt, 2003; Pagach \& Warr, 2007; Pagach \& Warr, 2011; Hoyt \& Liebenberg, 2011). The main drawback of these studies was that they did not create a comprehensive scale for measuring ERM, considering that it is caused by a multitude of combined behaviors to tackle specific situations; it is an incomplete measure, which explains the 
weak statistical significance of results (Mikes \& Kaplan, 2013; Bromiley et al., 2015). The adoption of an index has numerous advantages over the use of a binary indicator, due to its ability to measure via a broader scale to what extent ERM was implemented. Like in McShane et al. (2011), Baxter et al. (2013) and Beasley et al. (2015), we measured according to a score, ranging from zero to 14, in order to assess the degree of adoption of ERM practices. The use of multiple determinants better identifies ERM users. Moreover, as long as private firms had no obligation to disclose data about internal systems and processes, including ERM practices, the only way to look into the topic was by administration of a questionnaire to a sample of firms. Survey-based primary data collection is widely recognized as a dominant method amongst management researchers (Flynn et al., 1990; Scudder \& Hill, 1998), due to the lack of available good secondary data (Zimmerman, 2001).

We developed a questionnaire considering the experience of previous surveys documented in the literature and the COSO Framework, and considering the specific circumstance that the analysis was going to involve unlisted firms.

The questionnaire consists of 16 questions, split into two sections. The main purpose of Section One (two questions) was to identify the respondents' characteristics. Section Two (14 questions) addressed the degree of implementation of ERM practices within the firm. The calculation of our dependent variable is summarized in two stages: in the beginning, we considered the answers, each of which was based on a binary system (zero-one). After that, we summed each categorical variable to obtain a score (from zero to 14), which was used to define our dependent count non-negative integer variable, called $E R M$, which measures the extent to which the firms in our sample adopt ERM practices. Our ERM index can be considered a reliable measurement scale, given its high Cronbach's alpha value (0.939).

We chose the COSO Framework as a reference for our research because Italian companies prefer complying with such a standard (KPMG, 2012). Every item controls for at least one out of the eight interrelated components of ERM, as described in Table 1. 
Table 1. Definition of $E R M$

\begin{tabular}{|c|c|}
\hline $\begin{array}{l}\text { Components of ERM } \\
\text { (COSO, 2004) }\end{array}$ & Elements of the dependent variable ERM \\
\hline \multirow{4}{*}{ Internal Environment } & $\begin{array}{l}\text { 1. } 1 \text { for firms that provide training for the staff of their risk management departments; } 0 \\
\text { otherwise. }\end{array}$ \\
\hline & $\begin{array}{l}\text { 2. } 1 \text { for firms in which the Chief Risk Officer obtained at least one of the following } \\
\text { qualifications: Bachelor's Degree, Master's Degree or Ph.D.; } 0 \text { otherwise. }\end{array}$ \\
\hline & $\begin{array}{l}\text { 3. } 1 \text { for firms that set up a risk management department more than two years ago; } 0 \\
\text { otherwise. }\end{array}$ \\
\hline & $\begin{array}{l}\text { 4. } 1 \text { for firms that state reasons for setting up a risk management department that differ from } \\
\text { legal obligations; } 0 \text { otherwise. }\end{array}$ \\
\hline Objective Setting & $\begin{array}{l}\text { 5. } 1 \text { for firms that hope to at least: achieve strategic goals, protect assets, create corporate } \\
\text { governance procedures properly or monitor performance; } 0 \text { otherwise. }\end{array}$ \\
\hline Event Identification & $\begin{array}{l}\text { 6. } 1 \text { for firms that planned at least one of the following activities: organization of general } \\
\text { ERM activities, identification of risk throughout the firm, giving plenty of advice and } \\
\text { recommendations to improve ERM practices or application of an ERM policy within the } \\
\text { company; } 0 \text { otherwise. }\end{array}$ \\
\hline Risk Assessment & $\begin{array}{l}\text { 7. } 1 \text { for firms utilizing at least one of the following indicators: basic risk indicators, risk } \\
\text { maps or quantitative methods (value-at-risk, Monte Carlo simulation); } 0 \text { otherwise. }\end{array}$ \\
\hline Risk Response & $\begin{array}{l}\text { 8. } 1 \text { for firms considering at least one of the following kinds of risks: strategic, } \\
\text { environmental or operational; } 0 \text { otherwise. }\end{array}$ \\
\hline \multirow{2}{*}{ Control Activities } & 9. 1 for firms where risk regulations are in place; 0 otherwise. \\
\hline & 10. 1 for firms discussing the risks more often than once a year; 0 otherwise. \\
\hline Information and Communication & $\begin{array}{l}\text { 11. } 1 \text { for firms that report ERM activities at least to Top Management, Chief Executives or } \\
\text { departments inside the company; } 0 \text { otherwise. }\end{array}$ \\
\hline \multirow{3}{*}{ Monitoring } & 12. 1 for firms hiring a Chief Risk Officer; 0 otherwise. \\
\hline & $\begin{array}{l}\text { 13. } 1 \text { for firms that have either a dedicated risk management department or have one inside } \\
\text { the Internal Audit; } 0 \text { otherwise. }\end{array}$ \\
\hline & $\begin{array}{l}\text { 14. } 1 \text { for firms in which more than three employees work within the risk management } \\
\text { department; } 0 \text { otherwise. }\end{array}$ \\
\hline
\end{tabular}

Note: The description of the elements of the dependent variable ERM is based on Framework and Application Techniques, COSO (2004). ERM equals the sum of the scores for the 14 measures above.

\subsection{Explanatory Variables: The Measurement of Ownership Structure}

Following Round (1976), we argue that ownership structure is described by both ownership concentration and type of ownership.

In order to analyze ownership concentration and test whether shareholders' dispersion in our sample affects the adoption of ERM practices (Hypothesis 1), we devised a proxy for ownership dispersion (Dispersion), measured the total number of shareholders (Brav, 2009) and expected that when ownership dispersion increases, the $E R M$ index would improve. Consequently, a positive link between Dispersion and ERM would provide evidence that ERM serves as a monitor of large shareholders: it prevents them from maximizing their own interests at the expense of minority shareholders.

There is surprisingly limited extant research on how different types of block-shareholders affect ERM. Following prior research, we distinguish between three categories of main block-shareholders (Niemi, 2005; Brustbauer, 2016; Paape \& Speklé, 2012). More specifically, Government is a dummy variable that equals 1 if the majority of shares is owned by a public authority, state or government, and 0 otherwise. Additionally, General Industrial equals 1 if the majority of shares is controlled by a general industrial firm (as a company, an individual or a family group), 0 otherwise. Finally, Institutional is a categorical variable, which takes on a value of 1 if the majority of shares is owned by mutual and pension funds, nominees, a trust/trustees or a financial company, 0 otherwise.

In the computation of the statistical results of the analysis, as displayed in Table 3, we dropped Government in order to avoid a dummy variable trap. Overall, we expected a positive impact of Dispersion, a negative influence of 
General Industrial and no impact or a positive impact of Institutional on the ERM; these results would respectively confirm Hypotheses 2.a, 2.b and 2.c.

\subsection{Explanatory Variables: Controlling for Performance and Governance}

Based on previous studies, we identified two classes of control variables: firms' financial performance (Baxter et al., 2013; Pagach \& Warr, 2011; Beasley et al., 2008) and firms' corporate governance (Paape \& Speklé, 2012; Beasley et al., 2005).

We controlled performance via the factors of profitability, leverage and dimension.

In order to control for firms' profitability, we used return on assets (ROA), which is proxied by earnings before interest and taxes, and scaled by total assets at the beginning of year. Hoyt and Liebenberg (2011), focusing their attention on US publicly traded insurers, found that firms' Tobin's Q ratios and returns on assets were significantly related to ERM engagement. Other researchers documented the fact that ERM quality was positively associated with firms' performance (Andersen, 2008; Baxter et al., 2013). Hence, we hypothesize a positive impact of a firm's profitability on its adoption of ERM practices, as higher profitability (and therefore a larger availability of financial resources) should stimulate managers to procure a more sophisticated system for the management of risks. It is worth pointing out that high profitability is a barrier against risk, as firms that benefit from larger profitability would not be interested in engineering additional risky management actions. Thus, we examined the association between change in performance and ERM engagement, using $\triangle R O A$, which is the first-difference in performance (i.e., a oneyear change in earnings before interest and taxes, scaled by lagged total assets).

We also controlled for firms' leverage, proxied by debt-dependence ( $L E V)$, measured as debt provided by the banks that was scaled by total assets at the beginning of year. While Pagach and Warr (2007), Liebenberg and Hoyt (2003) and Hoyt and Liebenberg (2011) found a positive relationship between ERM adoption and leverage, Baxter et al. (2013) and Beasley et al. (2008) highlighted the opposite findings. For highly leveraged firms, the advantage of implementing an ERM program is that it can help to protect the firm against the eventuality of default (Baxter et al., 2013, Andersen, 2008; Gordon et al., 2009). However, those firms might lack the finances to invest in high-quality ERM.

Finally, we controlled for firms' dimensions and complexity, measuring SIZE, as the natural logarithm of total assets. The relationship between firm size and ERM practices is well documented in the literature, leading to the fairly unambiguous conclusion that size is a fundamental prerequisite for an adequate ERM system (Pagach \& Warr, 2011; McShane et al., 2011; Baxter et al., 2013; Beasley et al., 2015).

We controlled for firms' corporate governance by measuring the quality of external auditing and the eventuality that external auditing is mandatory for the firm.

We proxied the quality of external auditing by adopting the binary variable Big4, which equals 1 if the auditor is a Big 4 auditing company, and 0 otherwise (Becker et al., 1998; DeFond, 1992; Teoh \& Wong, 1993). In the context of the US's big corporations, Beasley et al. (2005) did find positive and significant association effects of audit quality on ERM, whereas, according to Paape and Speklé (2012), there is no such association.

Finally, we controlled for the eventuality that the private firms in our sample are owned by listed companies, using the proxy Listed, which equals 1 if the main block-owner is a listed company, and 0 otherwise. Public firms have to comply with Corporate Governance Codes, which pressure them to strengthen internal controls and subject them to mandatory audits. Moreover, auditing is mandatory for the subsidiaries of listed firms. Hence, subsidiaries of listed companies would probably adopt a higher level of ERM for compliance, decreasing auditing work demanded by external auditors (Desender \& Lafuente, 2012). This is also in line with the substitution theory, according to which there is a negative link between investment in internal auditing and external auditing fees (Mohamed et al., 2012). 
Lastly, we added to the model a control for industry characteristics, as prior studies suggest that ERM is influenced by the sectors in which firms operate (Beasley et al., 2008; Beasley et al., 2005; Kleffner et al., 2003). We included in our model industry dummies in order to capture any variability occurring at an industry level.

\subsection{Econometric Model}

We estimated cross-sectional models, using one-year's data for each firm. We elaborated data using econometric analysis in order to test the aforementioned hypotheses. Because the dependent variable is an ordinal variable, we used two logistic regression models (Binomial and Poisson) and regressed the following equation:

$$
\begin{aligned}
& \text { ERM }_{i}=\alpha_{o}+\beta_{i} \text { Dispersion }_{i}+\beta_{2} \text { Institutional }_{i}+\beta_{3} \text { General Industrial }_{i}+\gamma_{i} \text { ROA }_{i}+\gamma_{2} \Delta R O A_{i}+ \\
& \gamma_{s} \text { Leverage }_{i}+\gamma_{s} \text { Size }_{i}+\gamma_{s} \text { Big }_{i}+\gamma_{6} \text { Listed }_{i}+\eta_{k} \text { Industry }_{i}+\varepsilon_{i}
\end{aligned}
$$

Logistic regressions are preferred when the errors are not normally distributed. This assumption is often violated when utilizing the linear model. We prefer employing Binomial and Poisson estimates together with a set of robust standard errors (often called Huber-White errors) in order to deal with over-dispersion of count variable ERM (Kleiber \& Zeileis, 2008; Zeileis, 2006; Cameron \& Trivedi, 2010; Wooldridge, 2002). Thus, we used the family of generalized linear model regressions. We chose a Binomial model, where the upper bound, (14) was well known before the investigation. ERM should be seen as the sum of 14 independent Bernoulli (zero-one) random variables; the Poisson regression model was also used to assess further the robustness of our findings. To conclude, our independent variables are lagged one year in order to avoid an endogeneity problem, which was among the most important shortcomings of previous studies (Bromiley et al., 2015).

\section{SAMPLE}

\subsection{Data Collection}

We selected the sample from all of the unlisted Italian firms in the AIDA database, provided by Bureau van Dijk for the year 2011. Secondly, we excluded the firms operating in the financial and real estate industries, non-active firms, un-incorporated firms, public firms and the ones preparing their financial statements in an aggregate form. Furthermore, we excluded firms with missing data on total sales, total assets and total debt, getting a balanced sample of 457 firms. We dropped the firms with unavailable or invalid contact details (i.e., email address and telephone number) and, finally, we administered the questionnaire to a sample of 359 firms. We got in touch with the firms initially via email and, later, since we received only three replies (i.e., less than $1 \%$ of the sample), we contacted them via telephone with the intention of introducing our survey. Two reminders were made after the first contact. We collected data from the beginning of May to mid-December 2013. We got 78 replies, representing a reliable sample, as respondents comprised $21.73 \%$ of the original sample.

\subsection{Descriptive Statistics}

The test of equality of means provided in Table 2 shows that the group of respondents does not differ significantly from the group of non-respondents, because Sales, Assets, Return on Assets and Leverage for respondents do not differ with statistical significance from the values measured for non-respondents. We also performed the Wilcoxon rank-sum test and the results were unchanged. Respondents and non-respondents operate similarly in various industries, as described in the bottom part of Table 2. 
Table 2. Mean, standard deviation and tests of differences in means between respondents and non-respondents

\begin{tabular}{l|c|c|c|c|c|c|c|c}
\hline \multirow{2}{*}{ ERM } & \multicolumn{2}{|c|}{ (a) All firms } & \multicolumn{2}{c|}{ (b) Respondents } & \multicolumn{2}{c|}{ (c) Non-respondents } & \multicolumn{2}{c}{ Mean difference } \\
\cline { 2 - 9 } & Mean & Median & Mean & Median & Mean & Median & (b)-(c) & t-stat. \\
\hline Sales & - & - & 3.205 & 0.000 & - & - & - \\
\hline Assets & $51,062,763$ & $13,094,155$ & $39,550,465$ & $11,855,131$ & $52,793,526$ & $13,008,481$ & $-13,243,061$ & -0.511 \\
\hline ROA & $45,158,865$ & $12,484,351$ & $40,455,008$ & $12,720,161$ & $45,227,616$ & $11,865,213$ & $-4,772,608$ & -0.368 \\
\hline LEV & 0.032 & 0.029 & 0.035 & 0.030 & 0.030 & 0.028 & 0.005 & 0.445 \\
\hline & 0.672 & 0.677 & 0.653 & 0.610 & 0.675 & 0.686 & -0.023 & -0.631 \\
\hline Industry & & & & & & & \\
\hline Chemicals & 126 & $35.097 \%$ & 29 & $37.180 \%$ & 97 & $34.520 \%$ & \\
\hline Utilities & 20 & $5.571 \%$ & 5 & $6.410 \%$ & 15 & $5.338 \%$ & \\
\hline Constructions & 30 & $8.357 \%$ & 5 & $6.410 \%$ & 25 & $8.897 \%$ & \\
\hline Wholes. \& Retail & 98 & $27.298 \%$ & 21 & $26.923 \%$ & 77 & $27.402 \%$ & \\
\hline Transp. \& Log. & 23 & $6.407 \%$ & 4 & $5.128 \%$ & 19 & $6.762 \%$ & \\
\hline Service & 62 & $17.270 \%$ & 14 & $17.949 \%$ & 48 & $17.082 \%$ & \\
\hline Firms & $\mathbf{3 5 9}$ & $\mathbf{1 0 0} \%$ & $\mathbf{7 8}$ & $\mathbf{1 0 0 \%}$ & $\mathbf{2 8 1}$ & $\mathbf{1 0 0 \%}$ & \\
\hline
\end{tabular}

Along with two-sample t-test we perform Wilcoxon rank-sum test, p-values are never significant at the levels $0.10,0.05$ or 0.01 , respectively.

Some descriptive statistics for the sample of respondents are displayed in Table 2. Our sample covers a wide range of companies: some very small, some relatively large. They have mean (median) sales equal to $€ 39,550,465$ $(€ 11,855,131)$; the mean (median) of their assets is $€ 40,455,008(€ 12,720,161)$. They are generally not highly profitable, considering that they have an $R O A$ that is on average (median) equal to $3.5 \%(3.0 \%)$. They are highly leveraged, with Leverage in mean (median) equal to $65.3 \%$ (61.0\%). Our indicator $E R M$ has a mean (median) value of $3.2(0)$. The firm that has adopted the broadest portfolio of ERM practices ticked 14 out of the 14 actions that we included in the questionnaire. In total, 56 out of 78 respondents declared that they had no risk management department, sub-department or chief risk officer. 


\section{RESULTS}

Results of the empirical analysis are shown in Table 3.

Table 3. Impact of firm-specific characteristics on the adoption of ERM practices

\begin{tabular}{|c|c|c|c|}
\hline \multirow{2}{*}{ Independent variables } & \multirow{2}{*}{ Coef. } & Binomial & Poisson \\
\hline & & (1) & (2) \\
\hline Intercept & $\alpha_{o}$ & $\begin{array}{c}-5.27 * * \\
(-2.08)\end{array}$ & $\begin{array}{c}-1.86 \\
(-0.97)\end{array}$ \\
\hline Dispersion & $\beta_{1}$ & $\begin{array}{l}0.02 * * \\
(2.14)\end{array}$ & $\begin{array}{l}0.01 * \\
(1.88)\end{array}$ \\
\hline Institutional & $\beta_{2}$ & $\begin{array}{l}-1.03 \\
(-1.59)\end{array}$ & $\begin{array}{c}-0.73 \\
(-1.44)\end{array}$ \\
\hline General Industrial & $\beta_{3}$ & $\begin{array}{l}-1.23 * * \\
(-2.46)\end{array}$ & $\begin{array}{l}-0.93 * * \\
(-2.36)\end{array}$ \\
\hline ROA & $\gamma_{1}$ & $\begin{array}{c}0.90 \\
(0.43)\end{array}$ & $\begin{array}{c}0.78 \\
(0.48)\end{array}$ \\
\hline$\triangle \mathrm{ROA}$ & $\gamma_{2}$ & $\begin{array}{l}3.93^{* *} \\
(2.54)\end{array}$ & $\begin{array}{l}2.50 \text { *** } \\
(2.99)\end{array}$ \\
\hline Leverage & $\gamma_{3}$ & $\begin{array}{c}0.76 \\
(0.98)\end{array}$ & $\begin{array}{c}0.55 \\
(0.98)\end{array}$ \\
\hline Size & $\gamma_{4}$ & $\begin{array}{l}0.24 * \\
(1.71)\end{array}$ & $\begin{array}{l}0.18^{*} \\
(1.75)\end{array}$ \\
\hline Big4 & $\gamma_{5}$ & $\begin{array}{c}0.34 \\
(0.64)\end{array}$ & $\begin{array}{c}0.24 \\
(0.72)\end{array}$ \\
\hline Listed & $\gamma_{6}$ & $\begin{array}{l}2.13 * * * \\
(4.82)\end{array}$ & $\begin{array}{l}0.97 * * * \\
(3.18)\end{array}$ \\
\hline No. of observations & & 78 & 78 \\
\hline Log pseudolikelihood & & -275.91 & -233.34 \\
\hline McFadden's pseudo- $\mathbf{R}^{2}$ & & - & 0.22 \\
\hline
\end{tabular}

Firstly, looking at the results in columns (1) and (2), which display the regression previously described as Equation (1), the variables connected to firms' ownership structures can be considered significant determinants for the implementation of ERM in unlisted companies.

The proxy measuring ownership dispersion (Dispersion) is positively associated with ERM implementation $\left(\beta_{i}<0\right.$, $p<0.05)$. This relationship validates Hypothesis 1, supporting the expectation that firms controlled by a small number of shareholders, each of whom likely exerts significant control over the firm, will be reluctant to implement ERM practices. However, as ownership dispersion increases, the variable ERM arises. This probably happens because minority shareholders regard ERM as a means of protecting themselves from block-shareholders' expropriations. Consequently, when Type II Agency Conflicts are less frequent or absent, ERM is better developed.

The proxies measuring the type of ownership seem to be significant in the explanation of ERM implementation in unlisted corporations, mostly validating our expectations about Hypothesis 2.

Unfortunately, we did not find a significant effect of Institutional ownership on $E R M\left(\beta_{2}>0, p>0.10\right)$; therefore, we cannot validate sub-Hypothesis 2.a. Nevertheless, all other types of ownership affect $E R M$ significantly. The dummy General Industrial, has a negative and significant impact on $E R M\left(\beta_{3}<0, p<0.05\right)$. This validates our prediction under sub-Hypothesis 2.b, that when the main block-shareholder is a general industrial company, which mostly includes individual and family firms, the ERM system is less developed. Finally, governmental ownership (which 
was dropped in Table 3, as it is the base-variable) is relatively more influential than other types of ownership on $E R M$. This, in line with patronage agency theory, implies that government-block-owned firms are more shareholder focused, developing better ERM practices.

We also found significant impacts of some control variables on ERM. $\triangle R O A$ is highly and positively significant $\left(\gamma_{2}>0, p<0.05\right)$; this means that firms with a growing performance developed stronger ERM systems. Also, we found a significant and positive impact of Size on ERM $(\gamma>0, p<0.10)$, agreeing with a considerable number of earlier works (Pagach \& Warr, 2011; Beasley et al., 2005; Beasley et al., 2015; McShane et al., 2011; Paape \& Speklé, 2012). Finally, we found that firms controlled by listed companies (Listed) have better $E R M$ values $(\gamma>0, p<0.01)$ than those possessed by private firms. Collectively, these findings might be taken as evidence that a leading role in shaping ERM behavior inside a subsidiary company is played by its parent company (Arena et al., 2010).

Pseudo- $R^{2}$ is normally lower when compared to $R^{2}$ values typically encountered with a linear regression model. Unfortunately, weak Pseudo- $R^{2}$ values are frequent, but in the Poisson model, we find $21.79 \%$, which is a considerable result. Unreported variance inflation factors (VIFs) and correlations between the explanatory variables give no indication that multicolinearity or perfect correlation are serious issues in the multivariate analyses ${ }^{1}$.

\subsection{Implications of ERM for Research and Practice}

In this paper we discussed the implementation of ERM in private corporations considering the ownership structure of the firm (i.e., ownership dispersion and type of ownership), investigated through the lens of agency theory.

Agency conflicts in the Italian environment (the basis of our empirical analysis) are caused by the unique features of a corporate governance system that is characterized by the strong powers of the main block-shareholders, which affect and strictly monitor managers' behavior according to their own interests (Melis, 2000). Hence, minority shareholders in Italy are subject to larger expropriation problems in comparison with those in the US (Zingales, 1994). In this paper, we showed that firms with a higher degree of shareholders' ownership dispersion (i.e., firms characterized by a large number of small proprietors) resort better to ERM as a corporate governance mechanism. When a firm has many shareholders and its ownership is more dispersed, the probability that it will strengthen ERM practices is larger. By comparison, when a firm has a few shareholders and its ownership is more concentrated, there is a smaller possibility that ERM practices will be adopted. These findings suggest that more pervasive Type II Agency Conflicts limit robust ERM adoption in Italian private firms.

Secondly, the type of ownership has a significant effect on private firms' decisions about ERM adoption. We documented the fact that firms owned by general industrial companies, which feasibly are family- or individualcontrolled companies, value ERM less than their counterparts do. It is likely that family members are able to exercise monitoring activities on the company directly, and do not consider ERM implementation to be worthwhile. Besides, government-owned corporations, which are generally considered more stakeholder-focused when compared to other types of owners, are found to adopt ERM practices more readily. This confirms the patronage agency theory and the notion that, as an owner, a government is interested in social and political goals more than financial ones. Lastly, we cannot confirm that institutional block-shareholders are active investors in implementing ERM for corporate control, as we found no statistical significance in the results of the regression analysis.

\section{CONCLUSIONS}

In this paper, we verify the impact of private firms' ownership structure on the adoption of ERM practices in Italy. Despite the advantage of an unregulated environment, unlisted firms have been largely overlooked in the literature. This study emphasizes the relevance of ownership characteristics in an institutional environment where the Type II Agency Conflict dominates.

We documented how important ERM is for the corporate governance of a private firm, especially when the ownership structure leaves small shareholders unprotected. We evidenced some important variations among

\footnotetext{
${ }^{1}$ The highest VIFs for Binomial and Poisson models are 2.60 and 2.92, respectively. The highest Spearman and Pearson correlation is 0.56. 
different types of main block-shareholders. Overall, the findings highlight greater ERM maturity where ownership is more dispersed, showing that ERM plays a significant role in protecting small shareholders. Additionally, ERM is better developed in government-owned firms, but is less well developed in individual- and family-owned firms. Hence, type of ownership has a relevant role in the development of ERM in private corporations, documenting the fact that ownership concentration in the hands of a stronger main block-shareholder (provoking more intense Type II Agency Conflicts) is a disincentive to the adoption of better ERM practices.

This research makes a contribution to both academics and practitioners, considering that ERM in private firms is under-researched and that standard setters could take the opportunity to implement some guidelines for nonmandatory ERM adoption in private firms. This study might help policymakers to recognize when it is worth suggesting that a firm aligns to ERM standards, underlining the relevance of several determinants in making this choice. It helps close a visible gap in the literature, which should devote more attention to ERM practices in smaller and private corporations, notwithstanding the limits posed by the restricted dimension and complexity that generally characterize those corporations.

An interesting follow-up study would be to use other research methodologies as long as investigation into ERM in private firms is still in its infancy, and it might be of interest to study this issue more deeply so that we can benefit from insights borne by the complementarities of case studies and survey research methods.

\section{ACKNOWLEDGMENTS}

Authors gratefully thank Antonello Maruotti (University of Southampton and University of Rome Three) for insightful suggestions on the statistical models.

\section{AUTHOR BIOGRAPHIES}

Elisabetta Mafrolla is Assistant Professor in Accounting at University of Foggia, Italy. She got a degree in Economics (cum laude) in 2003 and a Ph.D. in Accounting in 2007. She is currently Senior Lecturer at University of Foggia and University of Rome Three. She is a member of the European Accounting Association. She is also an active member of the European Academy of Management, where she serves as PhD Doctoral Mentor during the Annual Doctoral Colloquium, since May 2014.

Eugenio D'Amico is Full Professor of Accounting since 2003. Currently, he is tenured Professor at University of Rome Three. He is in several scientific committees and editorial boards of Italian national and international journals. Also, he chairs and participates in several professional committees (Board of Directors and Board of Statutory Auditors).

Felice Matozza is currently a second year Ph.D. student in Accounting at University of Rome Three, Department of Business Studies. He got a Master's Degree in Business Administration and Management from University of Foggia and he is a former exchange student at University of Vaasa (Finland). He is a member of European Accounting Association. His main research interest is auditing. Email: felice.matozza@uniroma3.it

\section{REFERENCES}

Ali, C. B., \& Lesage, C. (2013). Audit pricing and nature of controlling shareholders: Evidence from France. China Journal of Accounting Research, 6(1), 21-34.

Andersen, T. J. (2008). The performance relationship of effective risk management: Exploring the firm-specific investment rationale. Long Range Planning, 41(2), 155-176.

Arena, M., \& Azzone, G. (2007). Internal audit departments: Adoption and characteristics in Italian companies. International Journal of Auditing, 11(2), 91-114.

Arena, M., \& Azzone, G. (2009). Identifying organizational drivers of internal audit effectiveness. International Journal of Auditing, 13(1), 43-60.

Arena, M., Arnaboldi, M., \& Azzone, G. (2006). Internal audit in Italian organizations: A multiple case study. Managerial Auditing Journal, 21(3), 275-292. 
Arena, M., Arnaboldi, M., \& Azzone, G. (2010). The organizational dynamics of Enterprise Risk Management. Accounting, Organizations and Society, 35(7), 659-675.

Baxter, R., Bedard, J. C., Hoitash, R., \& Yezegel, A. (2013). Enterprise risk management program quality: Determinants, value relevance, and the financial crisis. Contemporary Accounting Research, 30(4) Winter, 1264-1295.

Beasley, M. S., Branson, B. C., \& Pagach D. (2015). An analysis of the maturity and strategic impact of investments in ERM. Journal of Accounting and Public Policy, 34(3), 219-243.

Beasley, M.S., Clune, R., \& Hermanson, D.R. (2005). Enterprise risk management: An empirical analysis of factors associated with the extent of implementation. Journal of Accounting and Public Policy, 24(6), 521-531.

Beasley, M.S., Pagach, D., \& Warr, R. (2008). Information conveyed in hiring announcements of senior executives overseeing enterprise-wide risk management processes. Journal of Accounting, Auditing \& Finance, 23(3), 311-332.

Becker, C., DeFond, M., Jiambalvo, J., \& Subramanyam, K.R. (1998). The effect of audit quality on earnings management. Contemporary Accounting Research, 15(1), 1-24.

Berrone, P., Cruz, C., \& Gomez-Mejia, L. R. (2012). Socioemotional wealth in family firms: Theoretical dimensions, assessment approaches, and agenda for future research. Family Business Review, 25(3): 258-279.

Bhimani, A. (2009). Risk management, corporate governance and management accounting: Emerging interdependencies. Management Accounting Research (Editorial), 20(1), 2-5.

Blaskovich, J., Davis, C. J., \& Taylor, E. Z. (2012). Enterprise risks, rewards, and regulation. Journal of Applied Business Research, 28(4), 563-580. Retrieved from http://cluteinstitute.com/ojs/index.php/JABR/article/view/7041/7115.

Brav O. (2009). Access to capital, capital structure, and the funding of the firm. The Journal of Finance, 64(1), $263-308$.

Bromiley, P., McShane, M., Nair, A., \& Rustambekov, E. (2015). Enterprise Risk Management: review, critique, and research directions. Long Range Planning, 48(4), 265-276.

Brown, N. C., Pott, C., \& Wömpener, A. (2014). The effect of internal control and risk management regulation on earnings quality: Evidence from Germany. Journal of Accounting and Public Policy, 33(1), 1-31.

Brustbauer, J. (2016). Enterprise risk management in SMEs: Toward a structural model. International Small Business Journal, 34(1), 70-85.

Cameron A. C., \& Trivedi P.K. (2010). Microeconometrics Using Stata, Revised Edition. College Station, TX: Stata Press.

Chaganti, R., \& Damanpour, F. (1991). Institutional ownership, capital structure, and firm performance. Strategic Management Journal, 12(7), 479-491.

Committee of Sponsoring Organizations of the Treadway Commission. (2004). Enterprise Risk Management - Integrated Framework. Jersey City, NJ: AICPA.

De Zwaan, L., Stewart, J., \& Subramaniam, N. (2011). Internal audit involvement in enterprise risk management. Managerial Auditing Journal, 26(7), 586-604.

DeFond, M. L. (1992). The association between changes in client firm agency costs and auditor switching. Auditing: A Journal of Practice \& Theory, 11(1), 16-31.

Demidenko, E., \& McNutt, P. (2010). The ethics of enterprise risk management as a key component of corporate governance. International Journal of Social Economics, 37(10), 802-815.

Desender, K. A., \& Lafuente, E. (2012). The role of enterprise risk management in determining audit fees: Complement or substitute. In A. Jalilvand \& A.G. Malliaris (Eds.), Risk Management and Corporate Governance (pp. 5-27). New York, NY: Routledge.

DiMaggio, P.J., \& Powell W.W. (1983). The iron cage revisited: Institutional isomorphism and collective rationality in organizational fields. American Sociological Review, 48(2), 147-160.

Ellul, A., \& Yerramilli, V. (2013). Stronger risk controls, lower risk: Evidence from U.S. bank holding companies. The Journal of Finance, 68(5), 1757-1803.

Flynn, B.B., Sakakibara, S., Schroeder, R.G., Bates, K.A., \& Flynn, E.J. (1990). Empirical research methods in operations management. Journal of Operations Management, 9(2), 250-284.

Fraser, I., \& Henry, W. (2007), Embedding risk management: Structures and approaches. Managerial Auditing Journal, 22(4), 392-409.

Gao, S.S., Sung, M.C., \& Zhang, J. (2012). Risk management capabilities building in SMEs: A social capital perspective. International Small Business Journal, 31(6), 667-700.

Gates, S., Nicolas, J.-H., \& Walker, P. L. (2012). Enterprise risk management: A process for enhanced management and improved performance. Management Accounting Quarterly (Spring), 13(3), 28-38.

Gordon, L.A., Loeb, M.P., \& Tseng, C.-Y. (2009). Enterprise risk management and firm performance: A contingency perspective. Journal of Accounting and Public Policy, 28(4), 301-327.

Henschel, T. (2010). Typology of risk management practices: An empirical investigation into German SMEs. Journal of International Business and Economic Affairs, 1(1), 1-29.

Hope, O.-K. (2013). Large shareholders and accounting research. China Journal of Accounting Research, 6(1), 3-20.

Hope, O.-K., Langli J.C., \& Thomas, W.B. (2012). Agency conflicts and auditing in private firms. Accounting, Organizations and Society, 37(7), 500-517.

Hoyt, R. E., \& Liebenberg, A. P. (2011). The value of enterprise risk management. The Journal of Risk and Insurance, 78(4), 795-822. 
Institute of Chartered Accountants in England and Wales. (2005). Risk management among SMEs - executive report of discovery research, London: ICAEW Consultation \& Research Centre. Retrieved August 18, 2013, from http://www.cpaireland.ie/docs/default-source/business-resource/icaew---risk-management-among-smes.pdf?sfvrsn=2.

Kane, G. D., \& Velury, U. (2004). The role of institutional ownership in the market for auditing services: an empirical investigation. Journal of Business Research, 57(9), 976-983.

Kleffner, A. E., Lee, R. B., \& McGannon, B. (2003). The effect of corporate governance on the use of enterprise risk management: Evidence from Canada. Risk Management and Insurance Review, 6(1), 53-73.

Kleiber, C., \& Zeileis, A. (2008). Applied Econometrics with R. New York, NY: Springer Science+Business Media.

KPMG. (2012). L'Enterprise risk management in Italia, Milan: KPMG Advisory S.p.A.. Retrieved June 7, 2013, from http://www.kpmg.com/IT/it/IssuesAndInsights/ArticlesPublications/Documents/ERM-Nov-2012.pdf.

Kumar, P. \& Zattoni, A. (2014). Ownership, managerial entrenchment, and corporate performance (Editorial). Corporate Governance: An International Review, 22(1), 1-3.

La Porta, R., Lopez-de-Silanes, F., \& Shleifer, A. (1999). Corporate ownership around the world. The Journal of Finance, 54(2), 471-517.

Liebenberg, A.P., \& Hoyt, R.E. (2003). The determinants of enterprise risk management: Evidence from the appointment of chief risk officers. Risk Management and Insurance Review, 6(1), 37-52.

Lovata, L.M., \& Costigan, M.L. (2002). Empirical analysis of adopters of economic value added. Management Accounting Research, 13(2), 215-228.

Mafrolla, E., \& Matozza, F. (2014). Risk management and company size: a survey of Italian private companies. Management Control, 3, 87-108.

Maurer, F. (2009). Creating value through enterprise risk management. Journal of Applied Business Research, 25(3), 13-24. Retrieved from http://www.cluteinstitute.com/ojs/index.php/JABR/article/view/1023/1007.

McShane, M.K., Nair, A., \& Rustambekov, E. (2011). Does enterprise risk management increase firm value?. Journal of Accounting, Auditing \& Finance, 26(4), 641-658.

Melis, A. (2000). Corporate governance in Italy. Corporate Governance: An International Review, 8(4), 347-355.

Mikes, A., \& Kaplan, R. S. (2013). Towards a contingency theory of enterprise risk management (Working Paper 13-063). Boston, MA: Harvard Business School. Retrieved August 19, 2014, from http://www.hbs.edu/faculty/Publication\%20Files/13-063_5e67dffe-aa5e-4fac-a746-7b3c07902520.pdf.

Mohamed, Z., Mat Zain, M., Subramaniam, N., \& Wan Yusoff, W. F. (2012). Internal audit attributes and external audit's reliance on internal audit: Implications for audit fees. International Journal of Auditing, 16(3), 268-285.

Nair, A., Rustambekov, E., McShane, M., \& Fainshmidt, S. (2014). Enterprise risk management as a dynamic capability: A test of its effectiveness during a crisis. Managerial and Decision Economics, 35(8), 555-566.

Niemi, L. (2005). Audit effort and fees under concentrated client ownership: Evidence from four international audit firms. The International Journal of Accounting, 40(4), 303-323.

Paape, L., \& Speklé, R. F. (2012). The adoption and design of enterprise risk management practices: An empirical study. European Accounting Review, 21(3), 533-564.

Pagach, D., \& Warr, R. (2007). An empirical investigation of the characteristics of firms adopting enterprise risk management (North Carolina State University Working Paper). Raleigh, NC: College of Management North Carolina State University. Retrieved February 21, 2013, from http://www.ermsymposium.org/pdf/papers/Pagach.pdf.

Pagach, D., \& Warr, R. (2011). The characteristics of firms that hire chief risk officers. The Journal of Risk and Insurance, 78(1), $185-211$.

Petroni, A. (1999). Mapping the diffusion of advanced risk management practices among Italian small- and medium-sized firms. Risk Management and Insurance Review, 2(3), 125-140.

Round, D. K. (1976). The effect of the separation of ownership and control on large firm profit rates in Australia: An exploratory investigation. Rivista Internazionale Di Scienze Economiche e Commerciali, 23, 426-436.

Sarens, G., \& Christopher, J. (2010). The association between corporate governance guidelines and risk management and internal control practices: Evidence from a comparative study. Managerial Auditing Journal, 25(4), 288-308.

Sarens, G., \& De Beelde, I. (2006). Internal auditors' perception about their role in risk management: A comparison between US and Belgian companies. Managerial Auditing Journal, 21(1), 63-80.

Scudder, G.D., \& Hill, C.A., (1998). A review and classification of empirical research in operations management. Journal of Operations Management, 16(1), 91-101.

Shleifer, A., \& Vishny, R. W. (1994). Politician and Firms. The Quarterly Journal of Economics, 109(4), 995-1025.

Shleifer, A., \& Vishny, R. W. (1997). A survey of corporate governance. The Journal of Finance, 52(2), 737-783.

Spira, L. F., \& Page, M. (2003). Risk management: The reinvention of internal control and the changing role of internal audit. Accounting, Auditing \& Accountability Journal, 16(4), 640-661.

Tagliavini, P. (1995). Risk management: The state of the art in Italy. The Geneva Papers on Risk and Insurance, 20(76), 315324.

Teoh, S. H., \& Wong, T. J. (1993). Perceived auditor quality and the earnings response coefficient. The Accounting Review, 68(2), 346-366. 
Wiseman, R. M., \& Gomez-Mejia, L. R. (1998). A behavioural agency model of managerial risk taking. Academy of Management Review, 23(1), 133-153.

Wooldridge, J.W. (2002). Econometric analysis of cross section and panel data, London: The MIT press.

Zeileis, A. (2006). Object-oriented Computation of Sandwich Estimators. Journal of Statistical Software, 16(9), 1-16.

Zimmerman J. L. (2001). Conjectures regarding empirical managerial accounting research. Journal of Accounting and Economics, 32(1-3), 411-427.

Zingales, L. (1994). The value of the voting right: A study of the Milan stock exchange experience. Review of Financial Studies, $7(1), 125-148$. 


\section{NOTES}

